\title{
Seasonal dynamics of bacterial biofilms on the kelp Laminaria hyperborea
}

\author{
Mia M. Bengtsson*, Kjersti Sjøtun, Lise Øvreås \\ Department of Biology, University of Bergen, Box 7803, 5020 Bergen
}

\begin{abstract}
Seasonal variations of the cell density and bacterial community composition in biofilms growing on the surface of the kelp Laminaria hyperborea from 2 sites on the southwestern coast of Norway were investigated using total cell enumeration and denaturing gradient gel electrophoresis (DGGE) fingerprinting. The major taxonomical groups of bacteria inhabiting the biofilms were identified by DGGE band sequence classification. The microbial cell density of the biofilm appeared to be highly affected by the seasonal growth cycle of the kelp and was found to be lowest on growing kelp in March (minimum $8.3 \times 10^{2} \mathrm{cells}^{-2}$ ), while on non-growing kelp in July to February, it was around $1.0 \times 10^{7}$ cells $\mathrm{cm}^{-2}$ with large fluctuations. The composition of the bacterial community of the biofilm followed a continuous seasonal succession that may be explained by the influence of both biotic factors such as seasonal changes in the kelp substrate and abiotic factors such as seawater temperature. Planctomycetes and Alphaproteobacteria were frequently detected throughout the year, while Verrucomicrobia, Cyanobacteria, Gammaproteobacteria, Betaproteobacteria, and Bacteroidetes were more sporadically detected. The bacterial communities of the biofilm on kelp showed little overlap with that of the surrounding seawater.
\end{abstract}

KEY WORDS: Kelp · Bacteria $\cdot$ Biofilm $\cdot$ Marine $\cdot$ Seasonal dynamics $\cdot$ Seaweed $\cdot$ DGGE Resale or republication not permitted without written consent of the publisher

\section{INTRODUCTION}

Kelps (large brown algae of the order Laminariales) form the basis of extensive underwater ecosystems known as kelp forests, which are found on rocky coasts both in temperate seas and in upwelling zones in the tropics (Graham et al. 2007). Kelps are large contributors to primary production in these areas (Mann 2000), and the unique 3-dimensional habitats that kelp forests constitute make them biodiversity hotspots (Christie et al. 2003, Graham 2004, Coleman et al. 2007). In many countries, kelp is harvested for the extraction of industrially valuable chemicals such as alginate as well as for food production.

Bacteria associated with kelp are believed to be critically important in many processes in kelp forest ecosystems. Several studies have addressed the flow of matter in kelp forests in South Africa (Lucas et al. 1981, Stuart et al. 1981, Newell \& Field 1983). Their many findings highlight the important role of heterotrophic bacteria as secondary producers utilizing kelp-produced carbon. Norderhaug et al. (2003) showed experimentally that kelp material that had been partially degraded by naturally associated bacteria was a better food source than undegraded kelp for amphipods living in kelp forests. These studies have focused on the bacteria as a group and have not been able to identify the bacteria responsible for these processes. Other studies have aimed to describe the composition and spatial and temporal dynamics of the bacterial communities associated with kelp. Early studies (Chesters et al. 1956, Laycock 1974) focused on culturable bacteria associated with kelp and their degradation of kelp substances. Laycock (1974) also found a seasonal difference in the culturable bacteria from kelp manifested as a predominance of psychrophilic and mesophilic bacterial strains isolated in winter and summer, respectively. The application of scanning electron microscopy (SEM) and fluorescent stains enabled in situ enumeration of bacteria growing on kelp without the need of 
culturing. Corre \& Prieur (1990) studied the density and morphology of bacteria on the kelp Laminaria digitata using SEM. They found a change of the bacterial communities both in terms of the density of bacterial coverage and the morphology of the bacteria in response to the aging of the kelp tissue. In a recent study, Staufenberger et al. (2008) used molecular methods to investigate the bacteria associated with the kelp Saccharina latissima (as Laminaria saccharina). They could identify several different bacterial lineages based on $16 \mathrm{~S}$ ribosomal RNA gene sequences and found differences in the composition of the bacterial communities present on different morphological parts of the kelp. They also found indications of seasonal and geographical differences.

Laminaria hyperborea is the largest canopy-forming kelp in the Northern Atlantic. L. hyperborea is estimated to produce approximately 50 million tonnes of biomass (wet weight) annually along the Norwegian coast (Fredriksen 2003). It forms the raw material for industrial alginate extraction presently carried out in Norway, and the kelp forests are an invaluable resource for fisheries as they serve as nursing grounds for several commercially important species of fish (Norderhaug 2003). L. hyperborea consists of a smooth blade-like structure called the lamina that is attached to an upright and flexible stipe, which can be up to $3 \mathrm{~m}$ long. A holdfast structure at the bottom of the stipe attaches the kelp to the substrate. L. hyperborea has a pronounced seasonal growth pattern, as the lamina is renewed every year during a growth period lasting from January until June (Fig. 1). The most rapid growth takes place from March until May (Kain 1979). This generates fresh surface area for marine microbes to colonize and makes an excellent system to study natural biofilm succession and dynamics. The old lamina is shed in April and is replaced by a new lamina that has grown out since January. There is also a seasonal pattern of the carbon and nitrogen content of $L$. hyperborea cells (Sjøtun et al. 1996) as well as exudation of dissolved organic matter in the form of carbohydrates and phenolic compounds (Abdullah \& Fredriksen 2004). Because the contents and exudates of the kelp cells may be sources of nutrition for kelp-associated bacteria, seasonal variations in these are likely to be important factors controlling the bacterial communities on L. hyperborea.

In this study, biofilms growing on the surfaces of the kelp Laminaria hyperborea at different times of the year are described using total microbial cell enumeration as well as molecular fingerprinting and classification based on the 16S rRNA gene sequences of bacteria. We aimed to reveal some of the fundamental factors that control the composition and dynamics of bacterial communities in kelp forests by studying them in a seasonal context. This may lay a foundation for increased understanding of the roles of bacteria in kelp forests, which can ultimately shed more light on both the ecology of kelp forests and the dynamics of natural biofilms on living surfaces.

\section{MATERIALS AND METHODS}

Sampling of kelp biofilms and seawater bacteria. Kelp Laminaria hyperborea was collected by dredging from a boat at 2 sites outside Bergen, Norway (Stn 1: $60^{\circ} 30.505^{\prime} \mathrm{N}, 4^{\circ} 49.776^{\prime} \mathrm{E}$, Stn 2: $60^{\circ} 09.706^{\prime} \mathrm{N}$, $5^{\circ} 02.371^{\prime} \mathrm{E}$ ) at a depth of 5 to $9 \mathrm{~m}$. Sampling was performed at approximately 2 mo intervals evenly spread out throughout 2007, starting in early February and ending in late November. At each site and sampling occasion, 6 intact, full-grown (stipe length $>40 \mathrm{~cm}$ ) kelp individuals were selected from the kelp gathered by the rake-shaped specialized kelp dredge. The kelp individuals were transported to the laboratory in an insulated box and were processed within a few hours after sampling. Two different morphological regions

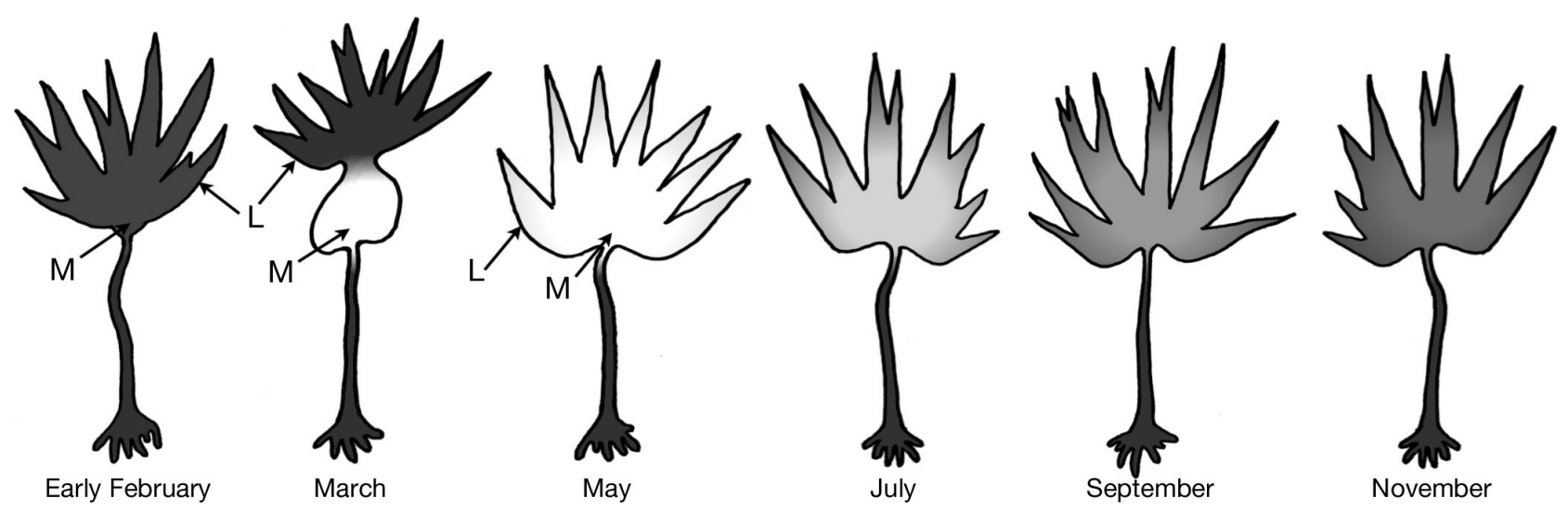

Fig. 1. Laminaria hyperborea. Morphology and different growth cycle stages of sampled kelp. Shading of the lamina (L) and meristem $(\mathrm{M})$ indicates the age of the surface tissue (light = younger, dark = older) 
from each kelp individual were sampled; the lower part of the lamina (meristematic region) and the middle part of the lamina (Fig. 1). These 2 regions are hereafter referred to as meristem and lamina. Areas that were heavily epiphytized, for example, by bryozoans and seaweeds, were avoided. A surface of approximately $50 \mathrm{~cm}^{2}$ from each region of every individual kelp plant (the area included both sides of the flattened thallus) was cut out and thoroughly rinsed with sterile seawater to remove any loosely attached contaminating bacteria originating from the sampling process. The kelp surface was scraped using a sterile scalpel, as microscopic inspection proved this method to be more effective in removing all attached bacteria than wiping with a cotton swab (results not shown). The scraped off material was suspended in $10 \mathrm{ml}$ of sterile phosphate-buffered saline (PBS, $137 \mathrm{mM} \mathrm{NaCl}$, $2.7 \mathrm{mM} \mathrm{KCl}, 10 \mathrm{mM}$ phosphate, $\mathrm{pH}$ 7.4) and mixed by vortexing. A volume of $1.5 \mathrm{ml}$ was immediately taken out from the suspension and centrifuged in order to pellet the bacterial cells. Pellets were kept at $-20^{\circ} \mathrm{C}$ until DNA extraction. One 0.51 water sample was also collected from a depth of $10 \mathrm{~m}$ at each site directly adjacent to where the kelp was collected. Water samples were filtered first onto $2.0 \mu \mathrm{m}$ and then onto $0.2 \mu \mathrm{m}$ polycarbonate membrane filters (GE Osmonics). Both filters were kept at $-20^{\circ} \mathrm{C}$ until DNA extraction.

Enumeration of microbial cells in the biofilm. Areas directly adjacent to the scraped areas of the meristem and lamina regions were used for cell enumeration. One small piece of kelp surface per kelp individual and region was cut out and fixed in a buffered $2 \%$ paraformaldehyde solution at $4^{\circ} \mathrm{C}$ overnight. The pieces were washed twice in ethanol:PBS (1:1) and kept in the same solution at $-20^{\circ} \mathrm{C}$ until DAPI staining. The kelp biofilms were stained by immersing approximately $0.25 \mathrm{~cm}^{2}$ kelp pieces in $2 \%$ DAPI solution for 10 min. The pieces were then rinsed in several volumes of sterile distilled water. Mounting on microscope slides was achieved by placing a piece of adhesive poster tack at the 4 corners of $25 \times 25 \mathrm{~mm}$ coverslips to create the correct distance between slide and coverslip to accommodate the thick (up to $3 \mathrm{~mm}$ ) kelp pieces. The kelp pieces were mounted in a few drops of Citifluor:Vectashield (4:1). Pictures of the stained biofilms were captured on a Zeiss AxioImager.Z1 fluorescent microscope with an AxioCam MRm digital camera (Zeiss Microimaging). Ten randomly selected but evenly distributed microscope fields were captured per sample kelp piece. Because of the 3-dimensional structure of the kelp surface and of the attached biofilm, it was necessary to capture several focal planes in order to visualize all biofilm cells in 1 microscope field. This was achieved by using the 'Z-stack' and 'extended focus' functions of the Zeiss AxioVision software. One 'extended focus' image was created for each microscope field consisting of information from several images captured at different focal planes with $1 \mu \mathrm{m}$ intervals through the entire depth of the biofilm of the sample. The number of images used to create the extended focus image varied between 5 and about 50, depending on the topography of the kelp surface and/or the biofilm thickness. The DAPI-stained cells were manually counted in each extended focus image. When an image contained more than approximately 200 cells, a grid with known dimensions was digitally overlaid on the image, and the cells within 10 predefined squares of the grid were counted. The cell density of each sample was estimated by calculating the average density of the 10 captured microscope fields.

DNA extraction. DNA from the pellets of scraped off material from the kelp surface layers was extracted using a modification of the method described by Øvreås et al. (2003b). Briefly, the pellet was suspended in a solution of lysozyme $\left(1 \mathrm{mg} \mathrm{ml}^{-1}\right)$ and RNAse $\left(0.5 \mathrm{mg} \mathrm{ml}^{-1}\right)$ in TE buffer $(10 \mathrm{mM}$ Tris- $\mathrm{HCl}, 1 \mathrm{mM}$ EDTA, pH 8) and incubated for $15 \mathrm{~min}$ at $37^{\circ} \mathrm{C}$. Proteinase $\mathrm{K}$ was added to a final concentration of $40 \mu \mathrm{g}$ $\mathrm{ml}^{-1}$, and samples were incubated for another $15 \mathrm{~min}$ at $37^{\circ} \mathrm{C}$. SDS was added to a concentration of $0.5 \mathrm{mg}$ $\mathrm{ml}^{-1}$, and samples were incubated at $55^{\circ} \mathrm{C}$ for $15 \mathrm{~min}$. Next, $\mathrm{NaCl}(5 \mathrm{M})$ was added to a concentration of $1 \mathrm{M}$ followed by a CTAB buffer $(10 \% \mathrm{w} / \mathrm{v}$ cetyl trimethylammonium bromide in $0.7 \% \mathrm{NaCl}$ ) to a final concentration of $1.6 \%$ CTAB. Samples were incubated at $65^{\circ} \mathrm{C}$ for $10 \mathrm{~min}$. An equal volume of chloroform: isoamylalcohol (24:1) was then added, and the samples were shaken on a vortexer for $10 \mathrm{~min}$. After a brief centrifugation, the aqueous phase was collected and precipitated in 0.6 volumes of isopropanol. The DNA pellet was washed in $70 \%$ ethanol, dried, and resuspended in PCR-grade water. The same method was used to extract DNA from whole membrane filters with filtered pelagic water samples.

PCR amplification of 16S rDNA. A part of the $16 \mathrm{~S}$ ribosomal RNA gene of bacteria including the V7 and V8 variable regions was amplified using the primers $1070 f$ (5'-ATG GCT GTC GTC AGC T-3') (Ferris et al. 1996) and 1392r (Lane et al. 1985) with an attached GC-clamp (5'-CGC CCG CCG CGC CCC GCG CCC GGC CCG CCG CCC CCG CCC CAC GGG CGG TGT GTR C-3'). Each $50 \mu \mathrm{l}$ PCR reaction contained nuclease-free water, F511 buffer (Finnzymes), $0.1 \mathrm{mM}$ of each dNTP (F506L, Finnzymes), 0.02\% BSA, $0.5 \mu \mathrm{M}$ of each primer, 0.02 U Dynazyme II F501-L (Finnzymes), and approximately $30 \mathrm{ng}$ template DNA. PCR conditions were: $94^{\circ} \mathrm{C}$ for $5 \mathrm{~min}, 30$ cycles of $94^{\circ} \mathrm{C}$ for $30 \mathrm{~s}, 50^{\circ} \mathrm{C}$ for $30 \mathrm{~s}, 72^{\circ} \mathrm{C}$ for $30 \mathrm{~s}$, and final elongation at $72^{\circ} \mathrm{C}$ for $7 \mathrm{~min}$. 
Denaturing gradient gel electrophoresis (DGGE) profiling of biofilm and seawater bacterial communities. PCR products were separated on 30 to $70 \%$ denaturant ( $7 \mathrm{M}$ urea and $40 \%$ deionized formamide) DGGE gels as described by Øvreås et al. (2003a). Gel images were captured with a ChemiGenius Bio Imaging System (Synoptics). All visible unique bands were picked for sequencing, and bands recurring several times on the same gel were picked at least twice. Band material was cut out from the gel and processed according to Øvreås et al. (1997), and reamplification of the bands was carried out using the same PCR conditions described in the previous section. A subset of the reamplified bands was run again on a second DGGE to check their purity. Reamplified bands were diluted 20 times with sterile water prior to sequencing.

Sequencing of DGGE bands. Sequencing was carried out using the BigDye Terminator v3.1 sequencing kit (Applied Biosystems). The $1070 \mathrm{f}$ primer was used in the sequencing reaction. The sequencing was carried out on an ABI 3700 sequencing system at the Bergen sequencing facility (www.seqlab.uib.no).

Sequence processing and analysis. Base calling of the sequence chromatogram files was done by the Phred software (Ewing et al. 1998), which also assigns a quality value to each base of the sequence. A strict quality filtering of sequences was carried out based on the Phred quality data. Bad quality ends of the sequences were cropped until the average quality of the distal 10 base pairs was above 25. Sequences that were shorter than 200 base pairs after cropping were discarded, as were sequences with an overall average quality below 33. A few additional sequences were subsequently removed from the analysis after manual inspection in the chromatogram viewer 4 peaks (www. mekentosj.com). The filtered sequences were aligned with MUSCLE (Edgar 2004), and the JalView alignment editor (Waterhouse et al. 2009) was used to trim the sequences to a similar length and to remove the GC-clamp at the end of each sequence. The resulting sequences were submitted to the NAST aligner (DeSantis et al. 2006a) of the Greengenes database project (DeSantis et al. 2006b). The NAST alignment was then used to assign a phylum to class level taxonomic classification to each sequence using the classify tool of Greengenes with the G2-chip as the chosen taxonomy. The NAST-alignment of the sequences was also used to create a distance matrix using the Greengenes distance matrix tool. The distance matrix was analyzed with DOTUR (Schloss \& Handelsman 2005), which assigns operational taxonomical units (OTUs) defined by different similarity percentages based on the distance matrix. An OTU definition of $95 \%$ similarity was adopted for this study, as it appeared to correspond well with the DGGE band positions. When using a $97 \%$ similarity definition, DGGE band sequences from the same position on a gel sometimes belonged to different OTUs. The OTUs were named by using the first letter(s) of the taxonomical group to which they belonged, followed by the number assigned to them by DOTUR. An OTU does not represent a bacterial species or any other natural taxonomical entity; it is merely a tool used for managing the sequence information obtained in the study in a convenient way.

DGGE image analysis. High-resolution printouts of the DGGE images were analyzed visually. To compare the banding patterns between many separate DGGE gels, the sequence information of the selected bands was used as an internal standard. This allowed the OTU composition of each sample to be deduced based on both the banding pattern and the OTU assignments of the sequenced bands on the same gel. Bands that were not chosen for sequencing but were located at the same position as the sequenced bands were assigned to the same OTU as the sequenced bands within each gel. Using this approach, most ( $80 \%)$ of the visible bands on the DGGE gels could be assigned to an OTU. OTUs were recorded as either present or absent in each sample.

Statistical analyses. Statistical analyses were performed using the R-project software (R Development Core Team 2009) including functions from the vegan package (Oksanen et al. 2009). The cell density dataset was square root transformed prior to analysis. Differences in biofilm cell densities were tested using 1-way analysis of variance (ANOVA; R function aov) and Tukey's honestly significant difference (HSD; R function TukeyHSD). The DGGE results were analyzed with non-metric multidimensional scaling (nMDS, R function metaMDS) using the Jaccard similarity metric to visualize the similarities between samples. Anosim (R function anosim) was used to measure the separation between samples from the different regions and seasons. For comparison between seasons, the presence/absence tables of the meristem and lamina region samples from the same kelp individual were pooled into 1 presence/absence table per kelp individual prior to the analyses. Samples containing less than 3 detected OTUs were removed from the analyses.

\section{RESULTS}

\section{Density of microbial cells in kelp surface biofilms}

The density and distribution of DAPI-stained microbial cells in the kelp surface biofilms was highly variable. This variation was seen between seasons (Figs. 2 \& 3), between replicate kelp individuals (Table 1 and Fig. 3), and between different microscope fields in 


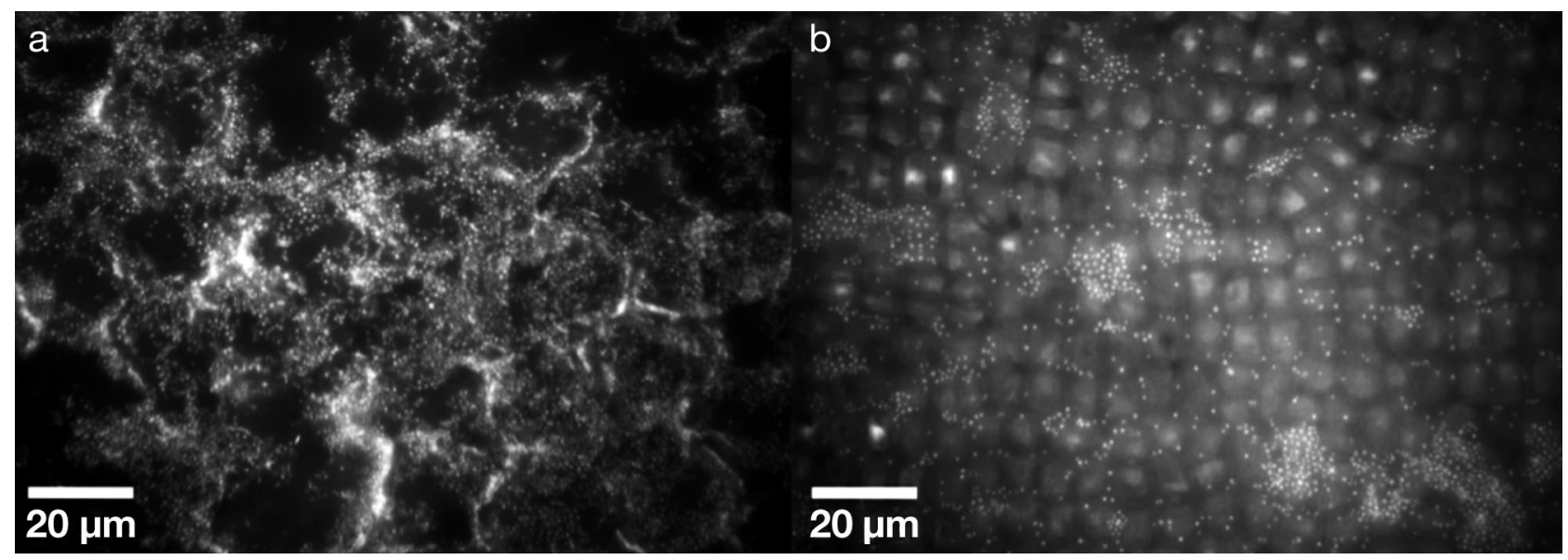

Fig. 2. Two examples of DAPI-stained biofilm from kelp. (a) Meristem region sampled in February (cell density: $\left.3.8 \times 10^{7}\right)$; $($ b) lamina region sampled in July (cell density: $1.3 \times 10^{7}$ ). Images are cropped and thus cover a smaller area than the whole microscope field images used for cell enumeration

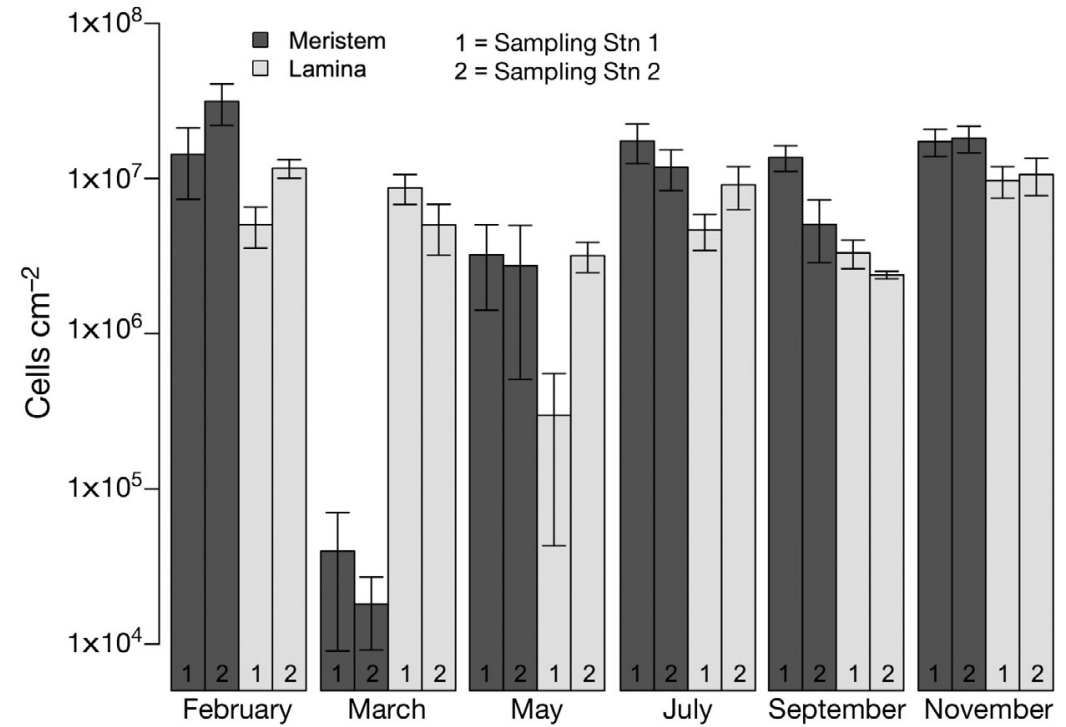

Fig. 3. Densities of DAPI-stained biofilm cells $\mathrm{cm}^{-2}$ on the meristem and middle lamina regions of kelp at different seasons represented as the mean of 6 replicate samples (except Stn 2 in March with only 2 replicates). Error bars represent SE

each sample (results not shown). Fig. 2 shows 2 examples of images captured of DAPI-stained biofilm cells, illustrating different biofilm architectures. The average cell densities on the meristem and lamina of kelp individuals from the 2 sampling stations throughout the year are summarized in Table 1 and visualized in Fig. 3. The large SDs of the average values in Table 1 and the large error bars (representing standard error, $\mathrm{SE}$ ) in Fig. 3 highlight the considerable variation of the cell density between replicate kelp individuals. The highest cell densities were seen in samples from the meristem region in February with sample averages close to $6.5 \times 10^{7}$ cells $\mathrm{cm}^{-2}$. The lowest densities were recorded in the rapidly growing meristem region in March with average cell numbers down to 8.3 $\times 10^{2}$ cells $\mathrm{cm}^{-2}$ in some samples. The overall average cell density across all seasons and kelp plant regions was 9.0 $\times 10^{6}$ cells $\mathrm{cm}^{-2}$ and the median density was $5.4 \times 10^{6}$ cells $\mathrm{cm}^{-2}$. Differences in cell densities between seasons, stations, and between meristem and lamina were tested with 1-way ANOVA, followed by Tukey's HSD test (see Appendix 1 for a complete list of $\mathrm{p}$ values). Although highly variable, the overall cell densities of both meristem and lamina during February, July, and November and of the lamina in March were not significantly different and hence appear not to be affected by season. However, the growing meristem in March at Stn 1 had significantly lower cell densities $(p<0.05)$ than the meristem region in all other months except May. The meristem in March at Stn 1 also had significantly ( $p<0.01)$ lower cell density than the lamina in March. The meristem region in March at Stn 2 appeared to have lower cell density than both the meristem of other months and the lamina in March, yet p-values are not consistently significant due to the low number of replicate samples (due to technical problems during sample processing, only 2 samples were included in the analysis) in March at Stn 2. In May, both the lamina and the meristem displayed cell densities that were significantly lower than in February, July, and November 
Table 1. Summary of the results, showing the numbers of denaturing gradient gel electrophoresis (DGGE) bands and operational taxonomical units (OTUs) within each taxonomical group and season. Mean $\left( \pm 1 \mathrm{SD}\right.$ ) cell densities $\left(\mathrm{cells}^{-2}\right.$ ) on the meristem and lamina of kelp individuals from the 2 sampling stations throughout the year are also shown. Seawater temperature measured at $10 \mathrm{~m}$ depth at times close to the sampling occasions in a nearby fjord is also included (J. Egge unpubl. data). N/A: not applicable

\begin{tabular}{|c|c|c|c|c|c|}
\hline & $\begin{array}{l}\text { No. of DGGE } \\
\text { bands }\end{array}$ & No. of OTUs & $\begin{array}{l}\text { Cell density, } \\
\text { meristem }\end{array}$ & Cell density, lamina & $\begin{array}{c}\text { Seawater } \\
\text { temperature }\left({ }^{\circ} \mathrm{C}\right)\end{array}$ \\
\hline \multicolumn{6}{|l|}{ Season } \\
\hline February & 88 & 22 & $2.3 \times 10^{7}\left( \pm 2.1 \times 10^{7}\right)$ & $8.3 \times 10^{6}\left( \pm 5.0 \times 10^{6}\right)$ & 6.3 \\
\hline March & N/A & N/A & $3.4 \times 10^{4}\left( \pm 6.4 \times 10^{4}\right)$ & $7.8 \times 10^{6}\left( \pm 4.4 \times 10^{6}\right)$ & 6.2 \\
\hline May & 65 & 11 & $3.0 \times 10^{6}\left( \pm 4.8 \times 10^{6}\right)$ & $1.7 \times 10^{6}\left( \pm 1.9 \times 10^{6}\right)$ & 8.3 \\
\hline July & 94 & 10 & $1.5 \times 10^{7}\left( \pm 1.0 \times 10^{7}\right)$ & $6.9 \times 10^{6}\left( \pm 5.6 \times 10^{6}\right)$ & 12.3 \\
\hline September & N/A & N/A & $9.4 \times 10^{6}\left( \pm 7.2 \times 10^{6}\right)$ & $2.9 \times 10^{6}\left( \pm 1.3 \times 10^{6}\right)$ & 10.3 \\
\hline November & 113 & 16 & $1.8 \times 10^{7}\left( \pm 8.2 \times 10^{6}\right)$ & $1.0 \times 10^{7}\left( \pm 6.0 \times 10^{6}\right)$ & 8.4 \\
\hline \multicolumn{6}{|l|}{ Taxonomical group } \\
\hline Planctomycetes & $167(46.4 \%)$ & 8 & & & \\
\hline Verrucomicrobia & $63(17.5 \%)$ & 5 & & & \\
\hline Cyanobacteria & $19(5.3 \%)$ & 1 & & & \\
\hline Bacteroidetes & $15(4.2 \%)$ & 3 & & & \\
\hline Alphaproteobacteria & $74(20.6 \%)$ & 5 & & & \\
\hline Betaproteobacteria & $8(2.2 \%)$ & 2 & & & \\
\hline Gammaproteobacteria & $13(3.6 \%)$ & 6 & & & \\
\hline Actinobacteria & $1(0.3 \%)$ & 1 & & & \\
\hline
\end{tabular}

with few exceptions. The cell density of the lamina region in September was also significantly lower than in February and November for Stn 2. The lamina region appears to have a lower average cell density than the meristem when the lamina is not growing at the meristem, i.e. in February, July, September, and November (see Fig. 1). However, these differences were not significant ( $p>0.18)$. There were also no significant $(p>0.13)$ differences in biofilm cell densities between the different sampling stations.

\section{DGGE profiling of kelp biofilm and seawater bacterial communities}

DGGE profiles from 112 individual samples from 4 seasons were included in the analyses. One example of a DGGE gel is shown in Fig. 4. Out of a subset of the picked and reamplified bands, a large majority (85\%) was represented as 1 clear band in the correct position when run on a second DGGE. Of the 426 bands that were sequenced, 141 were filtered out because of

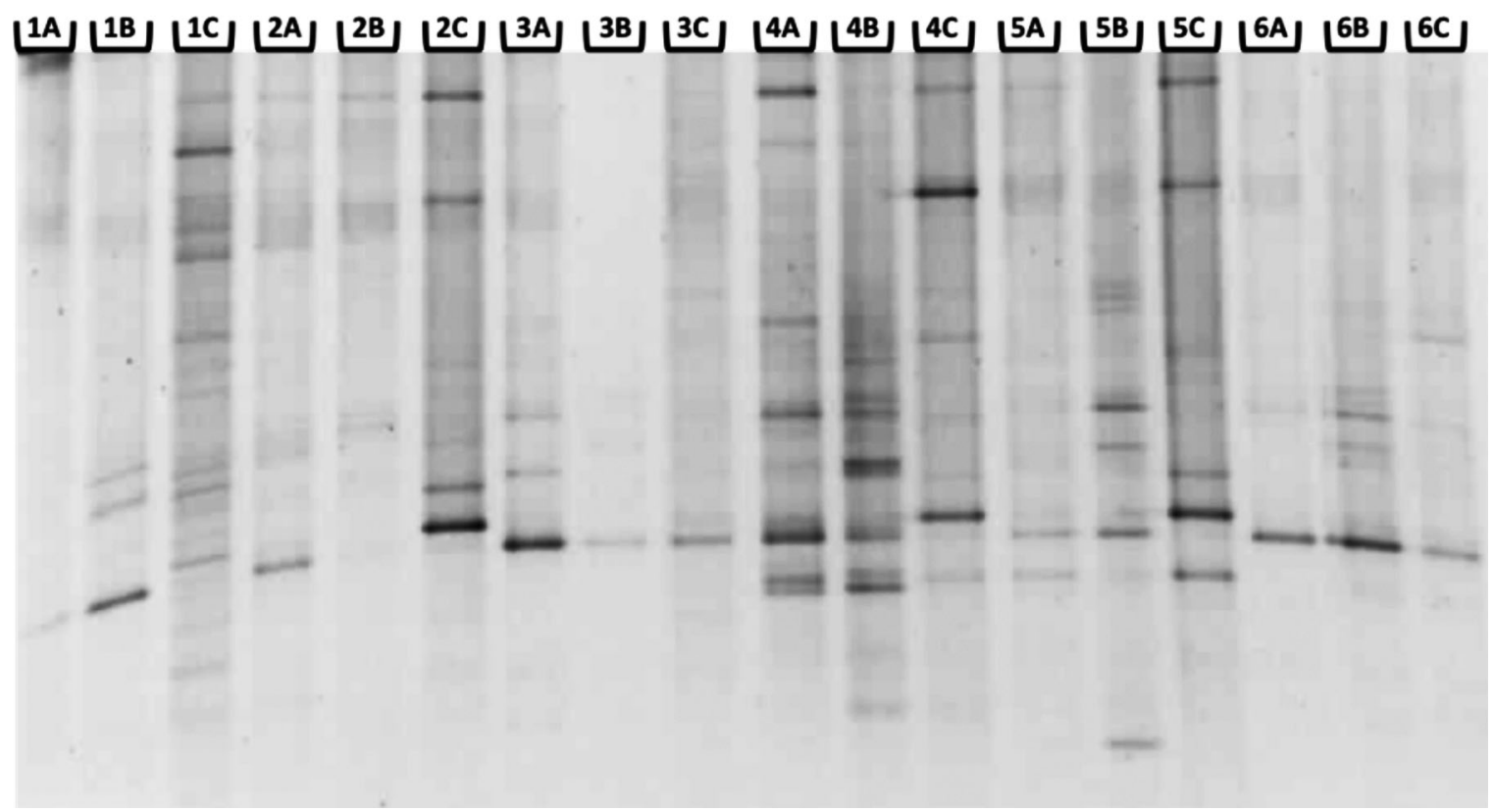

Fig. 4. Representative denaturing gradient gel electrophoresis (DGGE) gel used in the analysis of the seasonal dynamics of the bacterial communities on kelp. Numbers 1 to 6 represent different individual kelp plants, A to C designate the area of the kelp plant sampled. A: stipe (not included in the analyses), B: meristem, C: lamina. The gel shows samples from February 
insufficient quality, and 12 represented chloroplast and mitochondrial sequences and were removed from the analysis. The remaining 273 good quality, bacterial 16S rRNA gene sequences spread among 38 different OTUs using the $95 \%$ similarity OTU definition. When analyzing the DGGE images, 401 DGGE bands could be assigned to an OTU, which corresponds to $80 \%$ of the visible bands. Of these bands, 360 derived from kelp biofilm and 41 from seawater.

\section{Taxonomical classification of the DGGE band sequences}

The 360 DGGE bands deriving from kelp fell into 8 broad taxonomical groups (phylum and class) based on the Greengenes classification tool. These were Planctomycetes, Verrucomicrobia, Cyanobacteria, Bacteroidetes, Alphaproteobacteria, Betaproteobacteria, Gammaproteobacteria, and Actinobacteria, The number of DGGE bands belonging to each group in the different seasons is illustrated in Fig. 5. The most frequently detected group was the Planctomycetes, with a total number of 167 bands. A majority of the planctomycete sequences classified as Pirellulae (G2-chip taxonomy). The Alphaproteobacteria were also frequently detected (74 bands in total), where all sequences classified to the order Rhodobacterales. The number of OTUs that belonged to each group varied from only a single OTU within the Cyanobacteria to 8 different OTUs within the Planctomycetes. The numbers of

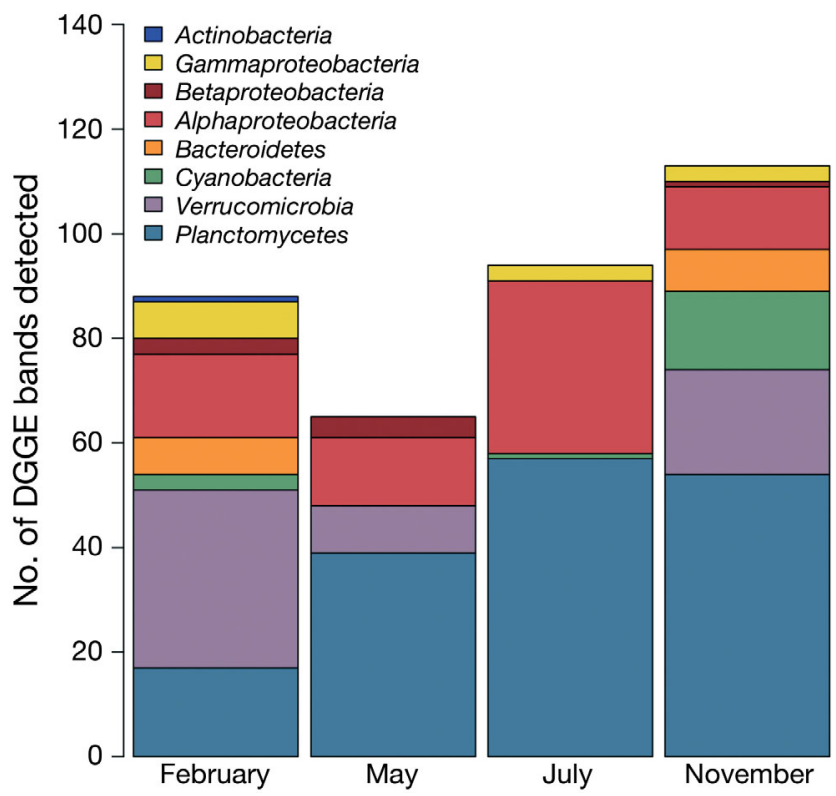

Fig. 5. Major groups of bacteria detected on kelp, shown as the number of denaturing gradient gel electrophoresis (DGGE) bands belonging to each group detected in the different seasons
DGGE bands and OTUs within each taxonomical group and season are summarized in Table 1. One representative sequence of each OTU was submitted to GenBank under accession numbers GU292011 to GU292048.

\section{Seasonal variation of bacterial community composition in kelp surface biofilms}

Analysis of the OTU composition of the 4 different seasons revealed seasonal changes in bacterial community composition in kelp surface biofilms. The nMDS ordination in Fig. 6a illustrates the seasonal pattern of biofilm community composition. Samples that are plotted closer to each other in the ordination have a more similar OTU composition than samples plotted farther away from each other. The samples from the respective seasons cluster together with varying degrees of overlap between the different seasons.

The degree of separation between the seasons was tested with Anosim. Table 2 shows the values of the Anosim statistic $\mathrm{R}$ when seasons were compared pairwise. $\mathrm{R}$ is scaled to have a value between -1 and +1 , where 1 corresponds to complete separation of the compared groups and 0 indicates no separation. According to a conventional interpretation of $\mathrm{R}$, values above 0.75 indicate completely separated groups, while $\mathrm{R}=0.5$ indicates that groups are clearly separated but overlapping and $\mathrm{R}=0.25$ indicates barely separable groups (Clarke \& Warwick 2001). The validity of $\mathrm{R}$ is assessed by a permutation test that gives a probability value ' $\mathrm{p}$ ' indicating whether $\mathrm{R}$ is meaningful for the tested dataset (Clarke 1993). In the pairwise comparisons between seasons, $\mathrm{R}$ values ranged between 0.35 and 0.77 , where the greatest separation $(\mathrm{R}=0.77, \mathrm{p}<0.001)$ occurred between May and November followed by July and November $(R=0.70, p$ $<0.001)$. The lowest separation was between February and May ( $\mathrm{R}=0.35, \mathrm{p}=0.007$ ).

Fig. $6 \mathrm{~b}$ shows the positions of the common OTUs ( $>4$ occurrences) in the nMDS ordination. Their position in relation to the seasonal $95 \%$ confidence ellipses indicates their influence on the seasonal clustering of the samples. For example, the Cyanobacteria OTU C17 that is positioned within the November ellipse, adjacent to the February and July ellipses (see Fig. 6b) was detected in February, July, and November, but was most frequently detected in November. The Planctomycetes OTU P40 was only detected in November, while P41 was detected in May and February. The Planctomycetes OTU P44 that is positioned centrally in the plot was common in all seasons and was detected in $78 \%$ of the samples. 

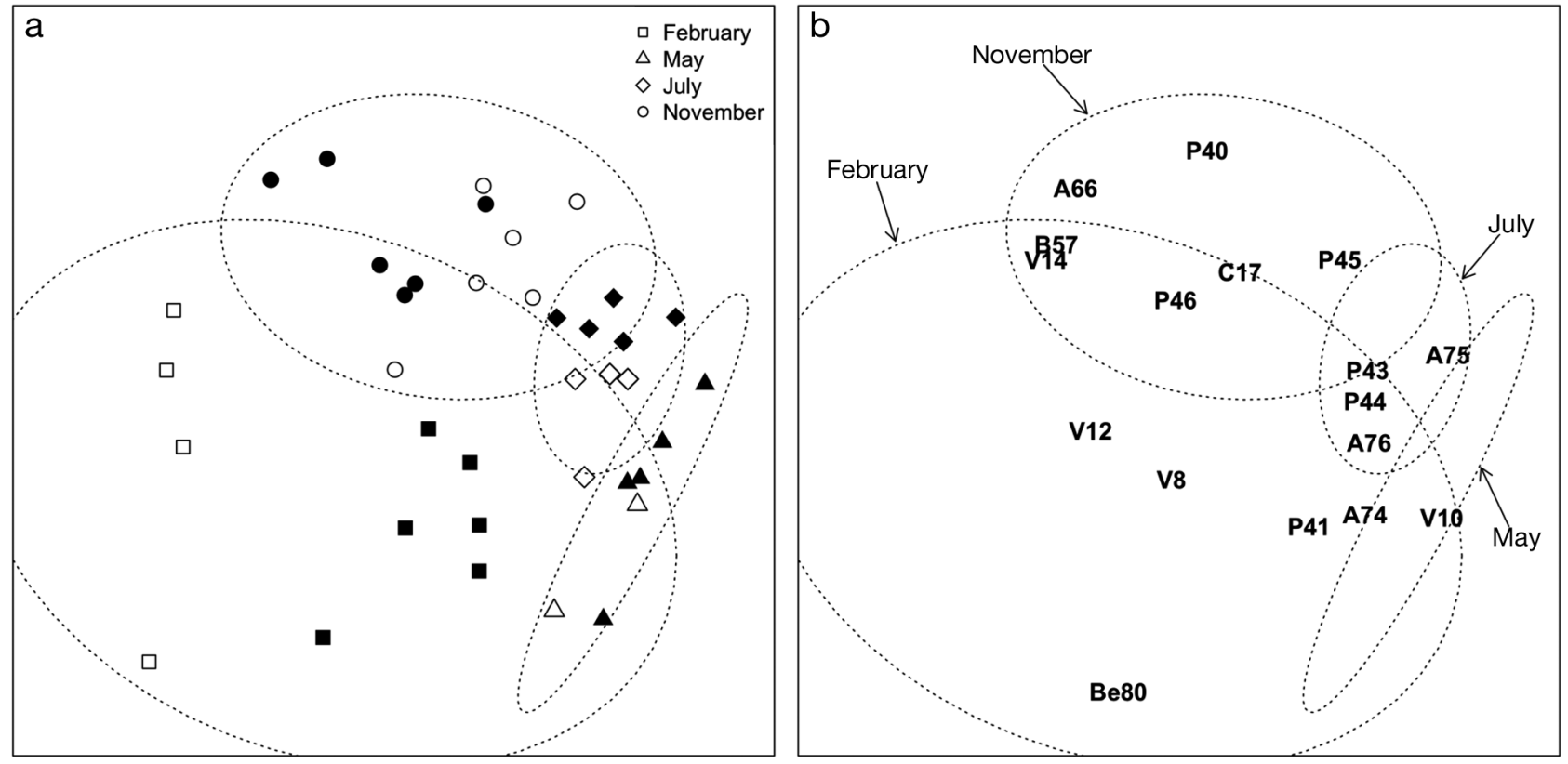

Fig. 6. (a) Non-metric multidimensional scaling (nMDS) ordination illustrating the similarity of samples from the 4 different seasons based on operational taxonomic unit (OTU) composition. Open (filled) symbols represent samples from Stn 1 (Stn 2). The dashed ellipses outline $95 \%$ confidence intervals of sample point position. (b) The same nMDS ordination where, instead of samples, common OTUs are displayed. Letter(s) of the OTU label indicate to which of the major taxonomic groups the OTU belongs. P: Planctomycetes, V: Verrucomicrobia, A: Alphaproteobacteria, C: Cyanobacteria, B: Bacteriodetes, Be: Betaproteobacteria. One OTU (P32) was omitted from the figure because it was in the same position as P44

Table 2. Values of the analysis of similarity (Anosim) statistic $\mathrm{R}$ from pairwise Anosim comparisons of the operational taxonomical unit compositions of the different seasons. All $R$ values $\mathrm{p}<0.001$

\begin{tabular}{|lcccc|}
\hline Season & February & May & July & November \\
\hline February & & 0.35 & 0.59 & 0.41 \\
May & & & 0.49 & 0.77 \\
July & & & 0.70 \\
November & & & & \\
\hline
\end{tabular}

Fig. 5 also suggests a seasonal pattern at a higher taxonomical level. Bands belonging to the Verrucomicrobia are absent in July, and the Bacteroidetes are represented only in February and November. Bands from the different taxonomical groups are more evenly distributed in February and November, while a few abundant groups dominate in May and July.

\section{Spatial variation of bacterial community composition in kelp surface biofilms}

No clear difference in the biofilm community composition between the 2 sampled regions of the kelp thallus, the meristem and the lamina was seen.
Within-season comparisons of the 2 regions yielded Anosim $R$ values for February $(R=0.15, p=0.10)$, May (0.41, $\mathrm{p}=0.06)$, July $(\mathrm{R}=0.10, \mathrm{p}=0.08)$, and November $(R=0.35, p=0.002)$. The $p$-values for February, May, and July indicate that the $\mathrm{R}$ statistic may not be reliable for these datasets, while the $\mathrm{R}$ statistic in November shows a slight difference between the 2 sampled regions.

A difference in the kelp biofilm community composition between sampling stations within seasons is indicated in Fig. 6a and was confirmed by Anosim in February $(\mathrm{R}=0.64, \mathrm{p}<0.001)$ and in July $(\mathrm{R}=0.46, \mathrm{p}<$ $0.001)$, while no significant difference could be demonstrated in May $(\mathrm{R}=-0.2455, \mathrm{p}=0.757)$ and November $(\mathrm{R}=0.09$, $\mathrm{p}=0.102)$.

\section{Bacterial community composition in kelp surface biofilms compared to seawater}

The 2 seawater samples collected during each season (1 from each station) showed little OTU overlap with kelp biofilm communities. In total, 3 OTUs (V10, P32, and A66) were found in both kelp biofilms and seawater. Only 1 of these (P32) was encountered in both kelp biofilms and seawater during the same season (July). V10 was detected in seawater in July, but 
was only detected in kelp biofilm in May and November. A66 was detected in seawater in May and July and in kelp biofilm in February and November.

\section{DISCUSSION}

The investigation of cell density and bacterial community composition of the microbial biofilms on the surfaces of the kelp Laminaria hyperborea at different times of the year revealed that seasonality has an important influence on the biofilms. However, seasonal changes include several different factors that can affect microbial biofilm communities. These include biotic factors such as kelp growth, exudation of substances by the kelp that are either antimicrobial or act as a food source, the composition of the microbial communities in the surrounding seawater, and the activity of grazers of kelp biofilms. Abiotic factors such as temperature, wave action, light conditions, and seawater nutrient levels may also be important. The seasonal context of this study allows evaluation and discussion of the influence of some of these different factors on kelp biofilms.

\section{Seasonal dynamics of cell density and community composition in kelp surface biofilms}

\section{March to May: establishment of the biofilm on new kelp substrate}

During spring, a rapid expansion of the kelp meristem tissue takes place and provides fresh substrate for colonizing bacteria (see Fig. 1). In March to April, this expansion corresponds to a lamina elongation of nearly $1 \mathrm{~cm} \mathrm{~d}^{-1}$ (Kain 1979, Sjøtun et al. 1996). The drastically reduced cell densities found on the meristem in March in this study (minimum $8.3 \times 10^{2}$, average $3.4 \times 10^{4}$ cells $\mathrm{cm}^{-2}$ ) are probably limited by the rate at which new kelp surface is produced. If this is the case, bacterial attachment and division does not happen at a rate sufficient to achieve higher cell densities on the rapidly expanding kelp surface. In addition, bacterial attachment and division may be suppressed by exudation of antibacterial substances such as phenols, which are high in March compared to other months (Abdullah \& Fredriksen 2004). The lamina region in March still consisted of old kelp tissue grown out the previous year and displayed cell densities that were comparable to other months, yet significantly higher than the growing meristem in March (see Fig. 3).

Two months later, in May, both the meristem and lamina regions consist of fresh tissue, and growth is still taking place at the meristem, but at a slower rate than in March (Kain 1979, Sjøtun et al. 1996). The cell densities of both meristem (average $3.0 \times 10^{6}$ cells $\mathrm{cm}^{-2}$ ) and lamina (average $1.7 \times 10^{6}$ cells $\mathrm{cm}^{-2}$ ) were still significantly lower in May (with few exceptions) compared to all other months except March, indicating that the biofilm was not yet fully established. The OTUs detected in May, which primarily belong to Planctomycetes, Verrucomicrobia, and Alphaproteobacteria, can be regarded as early colonizers of the fresh kelp substrate.

\section{July to February: maturation and succession of the biofilm}

The elongation of the kelp lamina stops in June (Kain 1979, Sjøtun et al. 1996), and the surface tissue is available for bacterial colonization and biofilm maturation until the lamina is shed in the next spring (see Fig. 1). From July to February, the cell densities of meristem and lamina appeared to stabilize at values close to $1.0 \times 10^{7}$ cells $\mathrm{cm}^{-2}$ (average $1.16 \times 10^{7}$ ), although fluctuations were large (Fig. 3, Table 1). Yet the biofilm community composition was constantly changing. This was evident both in the different biofilm architectures found in the microscopic images (Fig. 2) and in the DGGE results (Figs. 5 \& 6).

The bacterial community composition of the biofilm in July overlapped with that in May (Anosim R = 0.49) and was characterized by a stable community dominated by only a few OTUs within Planctomycetes and Alphaproteobacteria (see Fig. 5 and Table 2). The summer is a period of relatively high water temperatures, high photosynthetic activity of the kelp, and also high exudation rates of carbohydrates (Abdullah \& Fredriksen 2004). Such conditions are likely to be beneficial for heterotrophic bacteria that live on kelp exudates. The dominating OTUs in July may represent a highly specialized community adapted to life in kelp biofilms that is able to outcompete other bacteria. The frequently detected Planctomycetes OTU P44 is probably an example of one of these specialized bacteria.

In November, the community was supplemented with different OTUs within Planctomycetes, Alphaproteobacteria, Cyanobacteria, and Bacteroidetes. Many of these OTUs were also present in February. The biofilm in February was characterized by a diverse community including OTUs from all major taxonomical groups found in the study. The big spread of sample points from February in the nMDS ordination in Fig. 6a illustrates that there are big variations in the community composition between different kelp individuals. This diverse and unspecific community contrasted with the stable and specialized community in July and may be explained by the wide range of niches available for 
different bacteria involved in breaking down the aging kelp tissue in February. The result agrees well with the study of Staufenberger et al. (2008), who found that old laminas (phyloids) of the kelp Saccharina latissima displayed less specific bacterial communities than the younger meristem and stipe (cauloid) regions.

The Anosim R values showed a large degree of overlap between the bacterial communities in May and February ( $\mathrm{R}=0.35)$, indicating that some of the OTUs found on aging tissue in February also acted as early colonizers on the fresh tissue in May. This closes the apparent 'seasonal cycle' of bacterial community composition in kelp surface biofilms. It also shows that aging of the kelp substrate and the resulting maturation of the biofilm is not the only factor explaining the succession of the bacterial communities. Instead, other factors such as seawater temperature, which was similarly cold in February and May at the sampling sites (Table 1; J. Egge unpubl. data), may have contributed to shaping the bacterial communities. Laycock (1974) showed that seawater temperature selects for either psychrophilic or mesophilic culturable bacterial communities on the kelp Laminaria longicruis. Seawater temperature may be an important factor besides the biotic factors relating to the growth cycle of the kelp in controlling the bacterial community composition of kelp biofilms.

The similarity of the bacterial communities found between the aging lamina in February and the freshly grown out lamina in May also implies transmission of bacteria from old kelp tissue to young kelp tissue, either via the seawater or by direct contact. The stipe and holdfast regions of Laminaria hyperborea (not investigated in this study) are not renewed every year, and the biofilms residing on these older surfaces could serve as stock populations for biofilm bacteria colonizing fresh kelp surface tissue.

\section{Spatial dynamics of cell density and community composition in kelp surface biofilms}

The meristem has a lower content of phenolic substances than the lamina in Laminara hyperborea (Connan et al. 2006). This could potentially influence biofilms by causing differential exudation of substances in the different regions of the kelp that either have an antibacterial effect or act as a food source for the bacteria. No significant differences in cell density between the meristem and lamina regions could be demonstrated in this study, although the lamina appears to have a lower average cell density than the meristem (see Fig. 3). However, the large variations in cell density between kelp individuals and even different microscope fields shows that kelp biofilms are extremely heterogeneous, and stochastic variation could easily obscure general trends. A lower cell density in the lamina region could reflect its higher phenolic content, given that the phenolic substances have antimicrobial activity.

The meristem and lamina regions of the kelp sampled in this study showed slight differences in biofilm community composition only in November. These results support the findings of Staufenberger et al. (2008), who detected specific associations of bacterial communities with different parts of the kelp Saccharina latissima including the equivalents of the meristem and lamina.

The 2 sampling stations for kelp were chosen to be similar with respect to kelp size and morphology. Yet differences in the cover and composition of macroscopic epiphytes (red seaweeds for example) indicated that other environmental factors such as wave exposure may differ between the stations. Differences in bacterial community composition between kelps from the 2 different sampling stations in this study were evident only in February and July. The lack of difference in May and November may indicate that there are large stochastic variations between the sampled kelp plants that obscure differences between kelp plants from the different stations. The kelp forest is a heterogeneous environment, and local scale variations in depth, wave exposure, and currents, all factors that may influence bacterial biofilms growing on kelp, make it difficult to sample a representative selection of kelp plants from 1 station, especially with the dredging technique used in this study. The differences observed between the stations in July and February as well as the large variations within the stations are likely to be caused by local environmental factors rather than geographical distance.

\section{Regulation of the microbial cell density of kelp surface biofilms}

The overall cell density on kelp tissue in this study was around $1 \times 10^{7} \mathrm{cells} \mathrm{cm}^{-2}$. This number is comparable to cell densities recorded by Corre et al. (1990) on the closely related kelp species Laminaria digitata. This number is surprisingly low considering the rapid overgrowth by bacteria and other fouling organisms of most surfaces exposed to colonization in natural seawater (Zobell et al. 1935). The cell densities of both meristem and lamina are rather constant on the nongrowing kelp tissue from July to February. The exception to this rule is the lower cell density on the lamina in September, which is not easily explained by the seasonal aspects of kelp growth and exudation, and may reflect unknown environmental factors or unrepresen- 
tative sampling. The constant and low cell densities imply a regulation of the biofilm, preventing high cell densities. This may represent anti-fouling properties of the kelp, such as exudation of phenolic compounds (Arnold \& Targett 2002) or activated oxygen species (Küpper et al. 2001) to prevent settlement or growth of biofilm bacteria. The regulation may also be attributed to the biofilm bacteria themselves, which can control cell division and attachment within the biofilm by quorum sensing and production of inhibitory compounds. A recent study by Wiese et al. (2008) isolated and identified several bacterial strains producing antibiotics from the kelp Saccharina latissima (Laminaria saccharina). In addition, Rao et al. (2007) showed that biofilms grown from strains of epiphytic bacteria isolated from the marine seaweed Ulva australis inhibit settlement of bacteria and other fouling organisms at biofilm densities down to 100 cells $\mathrm{cm}^{-2}$.

\section{Bacterial community composition in kelp surface biofilms compared to the surrounding seawater}

Another factor influencing kelp biofilms may be the composition of the bacterial community of the surrounding seawater. As the results from the total microbial cell numbers in March and May showed, the new surface area formed during growth of the Laminaria hyperborea meristem was rapidly colonized by biofilm bacteria. One likely source of recruitment of bacteria is the surrounding seawater. Little overlap was found between the kelp biofilm and the seawater bacterial communities that were sampled in this study. Similar results have been reported in earlier studies on microbial biofilms on seaweed (Bolinches et al. 1988, Staufenberger et al. 2008). This shows that the dominant bacterial types are not the same in the kelp biofilm and the surrounding seawater. Therefore, biofilm bacteria must be recruited from less abundant populations in the seawater through selective processes or via transmission of bacteria by direct contact with surfaces. Due to limitations in the resolution of the DGGE technique, rare populations in the seawater are not easily detected. This makes it difficult to correlate fluctuations in the seawater bacterial communities with the composition of the bacterial communities in biofilms on kelp. Of the few OTUs that were detected in both seawater and kelp biofilm, most were not detected in both habitats during the same season. These OTUs may represent bacterial types alternating between a biofilm and free-living lifestyle on a seasonal basis. Alternatively, the OTUs may represent phylogenetically closely related but ecologically different bacterial types.

\section{Bacterial groups that inhabit kelp biofilms}

The most frequently detected groups were Planctomycetes, Alphaproteobacteria, Verrucomicrobia, and Cyanobacteria. These groups have relatively few OTUs in relation to the number of detected DGGE bands (Table 1). In contrast, Gammaproteobacteria have 6 OTUs among only 13 DGGE bands. This may indicate that Planctomycetes, Alphaproteobacteria, Verrucomicrobia, and Cyanobacteria make up a community consisting of a few specialized 'strains' adapted to life in kelp biofilms and are therefore consistently abundant. The different Gammaproteobacteria OTUs that occasionally reach high enough abundances to be detected in kelp biofilms may either be generalists that grow rapidly when competition is low or they may represent highly specialized strains that exploit rare niches on the kelp. Betaproteobacteria and Verrucomicrobia were only detected during February, May, and November, when the seawater temperature was below $10^{\circ} \mathrm{C}$, this may indicate a preference for cold seawater temperatures among these groups.

Interestingly, Planctomycetes, and Verrucomicrobia, which were frequently detected in this study, were not detected on the related kelp species Saccharina latissima in the recent study by Staufenberger et al. (2008). This may reflect a real difference in the bacterial community composition between the 2 different kelp species, but it may also result from a PCR primer bias, as Staufenberger et al. (2008) used a different 16S rRNA gene primer combination for clone library construction.

In summary, the seasonal fluctuations in cell density appear to be connected to the growth cycle of Laminara hyperborea, or more specifically, to the age of the kelp tissue. The cell densities in growing or young kelp tissue may be suppressed by rapid growth of the kelp substrate. The overall cell density is low and implies a strong regulation of kelp biofilms. On the OTU level, the biofilm community composition reflects a seasonal cycle, where the succession of bacterial OTUs is a continuous process during the year. May and November display the least similar biofilm communities, while February and May are highly overlapping. This successional pattern may only be explained by the combined influence of biotic factors relating to the growth cycle of the kelp and of abiotic factors such as seawater temperature. The community composition of the biofilm is characterized by a stable 'basal community' consisting of Planctomycetes and Alphaproteobacteria that has already established in the fresh kelp tissue in May. This community is supplemented with bacteria belonging to Gammaproteobacteria, Bacteroidetes, and Cyanobacteria as the kelp tissue is aging and the biofilm 
matures. Verrucomicrobia and Betaproteobacteria may be favored by colder seawater temperatures, as they are detected in February, May, and November but not in July. Seawater and kelp biofilm bacterial communities show little overlap.

Acknowledgements. We thank T. Sørlie, T. Urich, and D. Kohlmeier for assistance during sampling, J. Egge for the seawater temperature data, A. Lanzén for bioinformatics assistance, R. Telford for advice on the statistical analyses, and 3 anonymous reviewers for constructive comments on the manuscript. The study was funded by 2 scholarships from The Bergen University Fund and a donation from FMC BioPolymer (Philadelphia, PA).

\section{LITERATURE CITED}

Abdullah M, Fredriksen S (2004) Production, respiration and exudation of dissolved organic matter by the kelp Laminaria hyperborea along the west coast of Norway. J Mar Biol Assoc UK 84:887-894

Arnold T, Targett N (2002) Marine tannins: the importance of a mechanistic framework for predicting ecological roles. J Chem Ecol 28:1919-1934

Bolinches J, Lemos ML, Barja JL (1988) Population dynamics of heterotrophic bacterial communities associated with Fucus vesiculosus and Ulva rigida in an estuary. Microb Ecol 15:345-357

Chesters CGC, Apinis A, Turner M (1956) Studies of the decomposition of seaweeds and seaweed products by micro-organisms. Proc Linn Soc 166:87-97

Christie H, Jørgensen N, Norderhaug KM, Waage-Nielsen E (2003) Species distribution and habitat exploitation of fauna associated with kelp (Laminaria hyperborea) along the Norwegian coast. J Mar Biol Assoc UK 83:687-699

> Clarke KR (1993) Nonparametric multivariate analyses of changes in community structure. Aust J Ecol 18:117-143

Clarke AC, Warwick RM (2001) Change in marine communities: an approach to statistical analysis and interpretation, 2nd edn. PRIMER-E, Plymouth

> Coleman MA, Vytopil E, Goodsell PJ, Gillanders BM, Connell SD (2007) Diversity and depth-related patterns of mobile invertebrates associated with kelp forests. Mar Freshw Res 58:589-595

> Connan S, Delisle F, Deslandes E, Gall E (2006) Intra-thallus phlorotannin content and antioxidant activity in Phaeophyceae of temperate waters. Bot Mar 49:39-46

Corre S, Prieur D (1990) Density and morphology of epiphytic bacteria on the kelp Laminaria digitata. Bot Mar 33: 515-523

> DeSantis TZ, Hugenholtz P, Keller K, Brodie EL and others (2006a) NAST: a multiple sequence alignment server for comparative analysis of $16 \mathrm{~S}$ rRNA genes. Nucleic Acids Res 34:W394-W399

DeSantis TZ, Hugenholtz P, Larsen N, Rojas M and others (2006b) Greengenes, a chimera-checked 16S rRNA gene database and workbench compatible with ARB. Appl Environ Microbiol 72:5069-5072

Edgar RC (2004) MUSCLE: multiple sequence alignment with high accuracy and high throughput. Nucleic Acids Res 32: 1792-1797

Ewing B, Hillier L, Wendl M, Green P (1998) Base-calling of automated sequencer traces using phred. I. Accuracy assessment. Genome Res 8:175-185
Ferris MJ, Muyzer G, Ward DM (1996) Denaturing gradient gel electrophoresis profiles of 16S rRNA-defined populations inhabiting a hot spring microbial mat community. Appl Environ Microbiol 62:340-346

Fredriksen S (2003) Food web studies in a Norwegian kelp forest based on stable isotope $\left(\delta^{13} \mathrm{C}\right.$ and $\left.\delta^{15} \mathrm{~N}\right)$ analysis. Mar Ecol Prog Ser 260:71-81

Graham M (2004) Effects of local deforestation on the diversity and structure of southern California giant kelp forest food webs. Ecosystems 7:341-357

Graham MH, Kinlan BP, Druehl LD, Garske LE, Banks S (2007) Deep-water kelp refugia as potential hotspots of tropical marine diversity and productivity. Proc Natl Acad Sci USA 104:16576-16580

Kain JM (1979) A view of the genus Laminaria. Oceanogr Mar Biol Annu Rev 17:101-161

Küpper FC, Kloareg B, Guern J, Potin P (2001) Oligoguluronates elicit an oxidative burst in the brown algal kelp Laminaria digitata. Plant Physiol 125:278-291

Lane DJ, Pace B, Olsen GJ, Stahl DA, Sogin ML, Pace NR (1985) Rapid determination of $16 \mathrm{~S}$ ribosomal RNA sequences for phylogenetic analyses. Proc Natl Acad Sci USA 82:6955-6959

- Laycock RA (1974) The detrital food chain based on seaweeds. I. Bacteria associated with the surface of Laminaria fronds. Mar Biol 25:223-231

> Lucas MI, Newell RC, Velimirov B (1981) Heterotrophic utilization of mucilage released during fragmentation of kelp (Ecklonia maxima and Laminaria pallida). II. Differential utilization of dissolved organic components from kelp mucilage. Mar Ecol Prog Ser 4:43-55

Mann KH (2000) Ecology of coastal waters: with implications for management?. Blackwell Science, Malden, MA

Newell RC, Field JG (1983) The contribution of bacteria and detritus to carbon and nitrogen flow in a benthic community. Mar Biol Lett 4:23-36

Norderhaug KM (2003) Importance of macrofauna in transferring kelp forest primary production to higher levels in the food chain. PhD thesis, University of Oslo

Norderhaug K, Fredriksen S, Nygaard K (2003) Trophic importance of Laminaria hyperborea to kelp forest consumers and the importance of bacterial degradation to food quality. Mar Ecol Prog Ser 255:135-144

Oksanen J, Kindt R, Legendre P, O'Hara B, Simpson GL, Solymos P, Stevens MHH, Wagner H (2009) Vegan: community ecology package. R package version 1.15-4. Available at http://CRAN.R-project.org/package=vegan

> Øvreås L, Forney L, Daae F, Torsvik V (1997) Distribution of bacterioplankton in meromictic Lake Saelenvannet, as determined by denaturing gradient gel electrophoresis of PCR-amplified gene fragments coding for 16S rRNA. Appl Environ Microbiol 63:3367-3373

> Øvreås L, Bourne D, Sandaa R, Casamayor E and others (2003a) Response of bacterial and viral communities to nutrient manipulations in seawater mesocosms. Aquat Microb Ecol 31:109-121

> Øvreås L, Daae F, Torsvik V, Rodriguez-Valera F (2003b) Characterization of microbial diversity in hypersaline environments by melting profiles and reassociation kinetics in combination with terminal restriction fragment length polymorphism (T-RFLP). Microb Ecol 46:291-301

Rao D, Webb JS, Holmström C, Case R, Low A, Steinberg P, Kjelleberg S (2007) Low densities of epiphytic bacteria from the marine alga Ulva australis inhibit settlement of fouling organisms. Appl Environ Microbiol 73:7844-7852

Schloss PD, Handelsman J (2005) Introducing DOTUR, a computer program for defining operational taxonomic units and estimat- 
ing species richness. Appl Environ Microbiol 71:1501-1506

Sjøtun K, Fredriksen S, Rueness J (1996) Seasonal growth and carbon and nitrogen content in canopy and first-year plants of Laminaria hyperborea (Laminariales, Phaeophyceae). Phycologia 35:1-8

Staufenberger T, Thiel V, Wiese J, Imhoff JF (2008) Phylogenetic analysis of bacteria associated with Laminaria saccharina. FEMS Microbiol Ecol 64:65-77

Stuart V, Lucas MI, Newell RC (1981) Heterotrophic utilization of particulate matter from the kelp Laminaria pallida. Mar Ecol Prog Ser 4:337-348

Team RDC (2009) R: a language and environment for statistical computing. R Foundation for Statistical Computing,
Vienna. ISBN 3-900051-07-0. Available at www.R-project.org

Waterhouse AM, Procter JB, Martin DMA, Clamp M, Barton GJ (2009) Jalview version 2-a multiple sequence alignment editor and analysis workbench. Bioinformatics 25:1189-1191

Wiese J, Thiel V, Nagel K, Staufenberger T, Imhoff J (2008) Diversity of antibiotic-active bacteria associated with the brown alga Laminaria saccharina from the Baltic Sea. Mar Biotechnol

Zobell C, Allen EC (1935) The significance of marine bacteria in the fouling of submerged surfaces. J Bacteriol 29: $239-251$

Appendix 1. P-values from 1-way ANOVA followed by Tukey's HSD tests of differences in cell density between seasons, between meristem and lamina regions, and between sampling stations. Shaded cells represent p-values <0.05. M: meristem, L: lamina, 1: Stn 1, 2: Stn 2

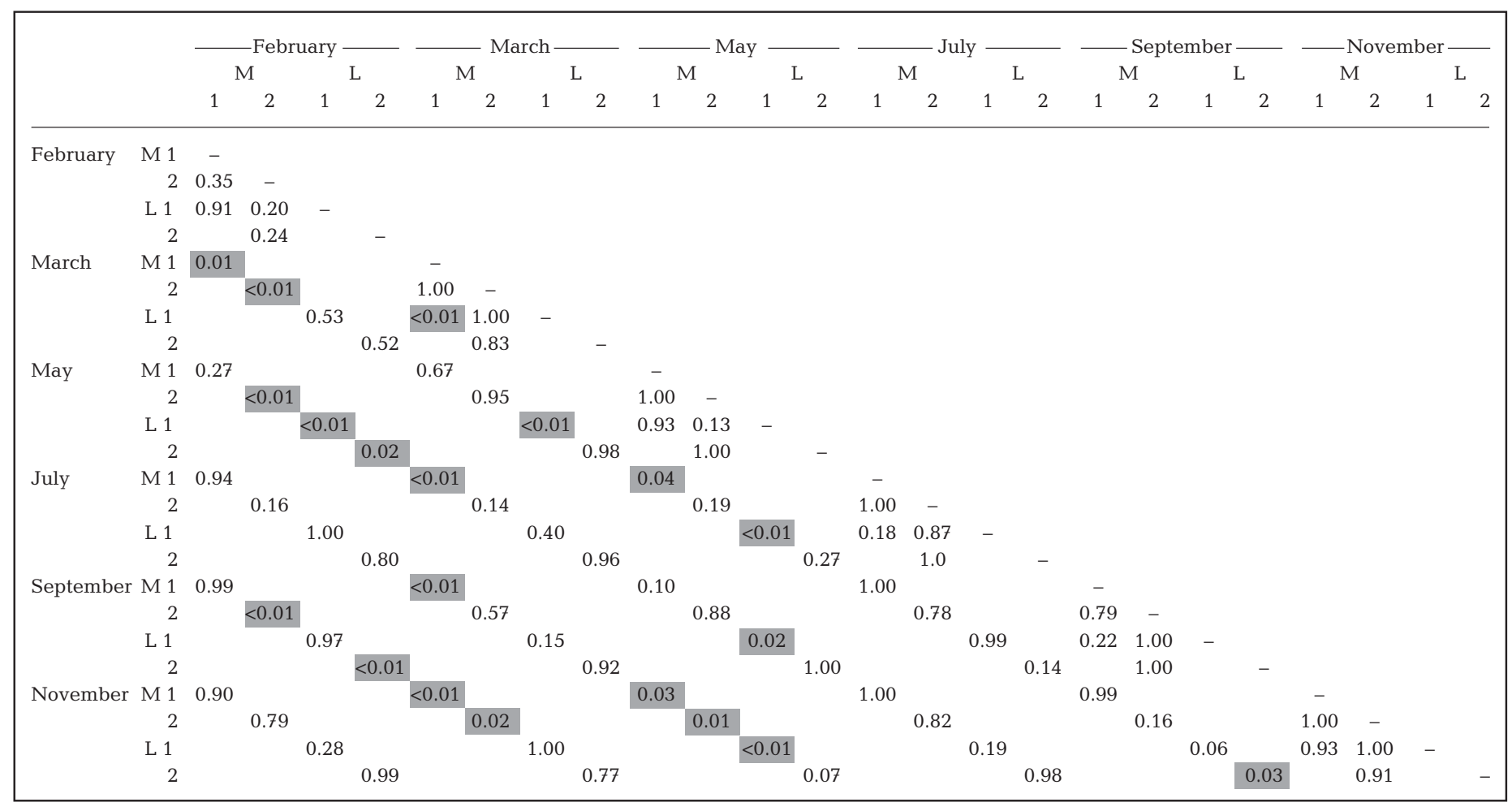

Editorial responsibility: Staffan Kjelleberg, Sydney, Australia
Submitted: December 14, 2009; Accepted: January 28, 2010 Proofs received from author(s): April 19, 2010 